\title{
JAMES HOGG
}

\section{The Three Perils of Man A Border Romance}

THE STIRLING / SOUTH CAROLINA RESEARCH EDITION OF THE COLLEGTED WORKS OF JAMES HOGG FOUNDING GENERAL EDITOR - DOUGLAS S. MACK GENERAL EDITORS - IAN DUNCAN AND SUZANNE GILBERT 
THE STIRLING / SOUTH CAROLINA RESEARCH EDITION OF THE COLLEGTED WORKS OF JAMES HOGG FOUNDING GENERAL EDITOR - DOUGLAS S. MACK

\section{GENERAL EDITORS - IAN DUNCAN AND SUZANNE GILBERT}

Volumes are numbered in the order of their publication in the Stirling / South Carolina Research Edition

1. The Shepherd's Calendar, ed. by Douglas S. Mack.

2. The Three Perils of Woman, ed. by David Groves,Antony Hasler, and D. S. Mack.

3. A Queer Book, ed. by P. D. Garside.

4. Tales of the Wars of Montrose, ed. by Gillian Hughes.

5. A Series of Lay Sermons, ed. by Gillian Hughes.

6. Queen Hynde, ed. by Suzanne Gilbert and Douglas S. Mack.

7. Anecdotes of $S$ cott, ed. by Jill Rubenstein.

8. The Spy, ed. by Gillian Hughes.

9. The Private Memoirs and Confessions of a Justified Sinner, ed. by P. D. Garside.

10. The Facobite Relics of Scotland: First Series, ed. by Murray G. H. Pittock.

11. Winter Evening Tales, ed. by Ian Duncan.

12. The Jacobite Relics of Scotland: Second Series, ed. by Murray G. H. Pittock.

13. Altrive Tales, ed. by Gillian Hughes.

14. The Queen's Wake, ed. by Douglas S. Mack.

15. The Collected Letters of James Hogg: Vol. 1 1800-1819, ed. by Gillian Hughes.

16. Mador of the Moor, ed. by James E. Barcus.

17. Contributions to Anmuals and Gift-Books, ed. by Janette Currie and Gillian Hughes.

18. The Collected Letters of James Hogg: Vol. 2 1820-1831, ed. by Gillian Hughes.

19. The Forest Minstrel, ed. by Peter Garside and Richard D. Jackson.

20. The Mountain Bard, ed. by Suzanne Gilbert.

21. The Collected Letters of James Hogg: Vol. 3 1832-1835, ed. by Gillian Hughes.

22. The Bush aboon Traquair and The Royal Fubilee, ed. by Douglas S. Mack.

23. Contributions to Blackwood's Edinburgh Magazine: Vol. 1 1817-1828, ed. by Thomas C. Richardson.

24. Midsummer Night Dreams and Related Poems, ed. by the late Jill Rubenstein and completed by Gillian Hughes.

25. Highland Fourneys, ed. by H. B. de Groot.

26. Contributions to Blackwood's Edinburgh Magazine: Vol. 2 1829-1835, ed. by Thomas C. Richardson.

27. The Three Perils of Man, ed. by Judy King and Graham Tulloch. 


\section{JAMES HOGG}

\section{The Three Perils of Man \\ or}

War, Women, and Witchcraft

A Border Romance

Edited by

Judy King and Graham Tulloch

With an Essay on the Manuscript

by Gillian Hughes

EDINBURGH UNIVERSITY PRESS

2012 
(C) Edinburgh University Press, 2012

Edinburgh University Press

22 George Square

Edinburgh

EH8 9LF

Typeset at the University of Stirling

Printed by CPI Antony Rowe, Chippenham, Wiltshire

ISBN 9780748638116

No part of this publication may be reproduced or transmitted in any form or by any means, electronic or mechanical, including photocopying, recording, or any information storage or retrieval system, without prior permission in writing from the publisher.

A CIP record for this book is available

from the British Library 
The Stirling / South Carolina Research Edition of

\section{The Collected Works of James Hogg}

\section{Advisory Board}

Chairman Dr Robin MacLachlan

General Editors Prof. Ian Duncan and Dr Suzanne Gilbert

Co-ordinator, University of South Carolina Prof. Patrick Scott

Co-ordinator, University of Stirling Dr Suzanne Gilbert

Ex Officio (University of Stirling)

The Principal

Head, Centre for Scottish Literature and Culture

Head, School of Arts \& Humanities

Research Officer, Division of Literature \& Languages

Members

Thomas Crawford (University of Aberdeen)

Dr Adrian Hunter (University of Stirling)

Dr Christopher MacLachlan (University of St Andrews)

Dr Anthony Mandal (Cardiff University)

Prof. Susan Manning (University of Edinburgh)

Prof. Murray Pittock (University of Glasgow)

Jackie Jones (Edinburgh University Press)

Prof. G. Ross Roy (University of South Carolina)

Prof. Roderick Watson (University of Stirling)

\section{The Aims of the Edition}

James Hogg lived from 1770 till 1835 . He was regarded by his contemporaries as one of the leading writers of the day, but the nature of his fame was influenced by the fact that, as a young man, he had been a self-educated shepherd. The second edition (1813) of his poem The Queen's Wake contains an 'Advertisement' which begins as follows:

THE Publisher having been favoured with letters from gentlemen in various parts of the United Kingdom respecting the Author of the QUEEN'S WAKE, and most of them expressing doubts of his being a Scotch Shepherd; he takes this opportunity of assuring the Public, that THE QUEEN's WAKE is really and truly the production of JAMES HOGG, a common shepherd, bred among the mountains of Ettrick Forest, who went to service when only seven years of age; and since that period has never received any education whatever. 
His contemporaries tended to regard the Scotch Shepherd as a man of powerful and original talent, but it was felt that his lack of education caused his work to be marred by frequent failures in discretion, in expression, and in knowledge of the world. Worst of all was Hogg's lack of what was called 'delicacy', a failing which caused him to deal in his writings with subjects (such as prostitution) which were felt to be unsuitable for mention in polite literature.

A posthumous collected edition of Hogg was published in the late 1830s. As was perhaps natural in the circumstances, the publishers (Blackie \& Son of Glasgow) took pains to smooth away what they took to be the rough edges of Hogg's writing, and to remove his numerous 'indelicacies'. This process was taken even further in the 1860s, when the Rev. Thomas Thomson prepared a revised edition of Hogg's Works for publication by Blackie. These Blackie editions present a comparatively bland and lifeless version of Hogg's writings. It was in this version that Hogg was read by the Victorians, and he gradually came to be regarded as a minor figure, of no great importance or interest.

Hogg is thus a major writer whose true stature was not recognised in his own lifetime because his social origins led to his being smothered in genteel condescension; and whose true stature was obscured after his death because of a lack of adequate editions. The poet Douglas Dunn wrote of Hogg in the Glasgow Herald in September 1988: 'I can't help but think that in almost any other country of Europe a complete, modern edition of a comparable author would have been available long ago'. The Stirling / South Carolina Edition of James Hogg seeks to fill the gap identified by Douglas Dunn. When completed the edition will run to thirty-nine volumes, and it will cover Hogg's prose, his poetry, his letters, and his plays.

The late Douglas S. Mack founded the edition and served as General Editor, and driving force, from its inception until his death in December 2009. Peter Garside, Suzanne Gilbert, and Gillian Hughes joined the editorial team as Associate General Editors in 1998; and in 2000 Gillian Hughes was appointed joint General Editor (with Douglas Mack), a position she held for ten years. In 2009 Peter Garside retired from the editorial team, and Ian Duncan and Suzanne Gilbert were named General Editors.

\section{General Editors' Acknowledgements}

We record with gratitude the support given to the Stirling / South Carolina Research Edition of the Collected Works of James Hogg by the University of Stirling and by the University of South Carolina. Valuable grants or donations have also been received from the Arts and 
Humanities Research Council, from the Carnegie Trust for the Universities of Scotland, from the Modern Humanities Research Association, from the Association for Scottish Literary Studies, and from the James Hogg Society. The work of the Edition could not have been carried on without the support of these bodies. Peter Garside initially served as the General Editor for the present volume and was followed by Douglas Mack; Suzanne Gilbert took over that role after Professor Mack's death.

The value of Douglas Mack's scholarly legacy in studies of Hogg, Scottish literature, and Romanticism cannot be overstated. For this intellectual energy, but also for his optimism, determination, and encouragement, he is greatly missed.

\section{Volume Editors' Acknowledgements}

The volume editors would like to express theirvery strongly felt thanks to the three general editors who at different times oversaw this volume. Peter Garside provided much valuable advice on editorial policy and the shape and content of the introduction. Douglas Mack gave us his energetic support and constantly helpful advice and continued to do so right up to the time of his much lamented death: this volume would not have come into being without his inspiring leadership in Hogg studies and his individual support to us as editors. Suzanne Gilbert helped us greatly in completing the volume and in particular undertook the immense and complex task of reconciling incompatible files and typesetting new files, working tirelessly in the final stages to give this volume its present splendid appearance. We are very much indebted to all of them.

We would also like to offer special thanks to Gillian Hughes for her expert assistance and encouragement throughout the project. When we started work we were ignorant, like most scholars, of the existence of the manuscript of The Three Perils of Man in the Fales Library of New York University. Gillian Hughes not only unearthed the manuscript but gave us free access to her transcript of it, which was of enormous help to us in our own work on the text. Her comprehensive essay in this volume draws on her unsurpassed knowledge of the manuscript and of Hogg's life and works. We are very grateful for all that she has contributed.

We also give our thanks for permission to use and quote from Hogg's manuscript of The Three Perils of Man in the Fales Library, New York University, and his manuscript of a proposed linking passage for The Siege of Roxburgh in the Stirling University Library. Our particular thanks go to current and former staff of the following libraries: the Fales Library (especially Mike Kelly for his welcome and assistance when 
viii

Graham Tulloch visited the Library); Flinders University Library (in particular Gillian Dooley, Lynda Clarke and the Document Services Unit, and Andrew Tufts); Stirling University Library (especially Helen Beardsley); the Baillieu Library of the University of Melbourne; the Barr Smith Library of the University of Adelaide; the State Library of South Australia; and the State Library of Victoria. We would also like to thank Jim Lewis for producing the excellent maps, Deborah Kilpatrick and Marguerite Nesling for help with the proofreading, and Barbara Leonardi for adjusting page references in the proofs. Our special thanks also to friends and colleagues who have advised and encouraged us in this project, in particular Ian Duncan (both before and after he became one of the General Editors of this Edition), Penny Fielding, Alison Lumsden, and Caroline McCracken-Flesher.

The Australian Research Council and Flinders University through the Faculty of Humanities, Education, Law and Theology have provided substantial financial support without which this research could not have been completed and for which we are very grateful.

Finally Judy King thanks Alan Mayne, her companion on this as on every journey, and Graham Tulloch thanks his wife, Sue, for her acceptance of yet another long-staying editorial child in their household. We could not have completed this volume without their love and support. 